\title{
EXTRACTION, PURIFICATION AND CHARACTERIZATION OF A PEPTIDOGLYCAN HYDROLASE FROM VEGETATIVE CELLS OF CLOSTRIDIUM PERFRINGENS TYPE A
}

\author{
RONALD G. LABBÉ, ${ }^{*}$ HSIAO-PING LU, AND SHIRLEY TANG \\ Food Microbiology Laboratory, Department of Food Science, \\ University of Massachusetts, Amherst, Massachusetts 01003 U.S.A.
}

(Received July 30, 1990)

\begin{abstract}
A peptidoglycan hydrolase $(\mathrm{PGH})$, which causes the germination and lysis of the coat-stripped spores of Clostridium perfringens, was extracted from perfringens vegetative cells. The enzyme was partially purified and showed an MW of 125,000 and a $\mathrm{p} I$ of 7.6. It was sensitive to a variety of monovalent and divalent cations and was inhibited by sulfhydryl-active agents. The sites of PGH action, the cell wall and the spore-cortex, were determined by the release of free amino groups from cell wall fragments and the release of soluble fluorescent products from fluorescamine-labelled cortical fragments of the $C$. perfringens spores. The enzyme appears distinct from the extracellular initiation protein produced by $C$. perfringens. PGH may be an autolysin with corticolytic activity.
\end{abstract}

Clostridium perfringens is a common cause of human food poisoning in Western countries. Illness results from the ingestion of large numbers of vegetative cells which sporulate and produce an enterotoxin in the intestine (30). The organism is commonly found in raw meat and poultry, frequently in the spore state. Temperature abuse of food allows germination and subsequent multiplication of vegetative cells.

In previous papers we have described the extraction and isolation of a spore-lytic enzyme (SLE) from whole spores of $C$. perfringens $(15,16)$. And we have previously isolated and characterized an extracellular spore-lytic (germination) enzyme from vegetative cells of this organism $(12,25,27,34,35)$. The latter enzyme causes the germination of coatless spores and hydrolysis of cortical fragments of this organism. The enzyme was termed initiation protein (IP) by Cassier and Sebald (6) who first detected it by its ability to promote recovery of heat-injured spores of this organism, presumably by replacing the inactivated, native, spore-germination enzyme.

* Address reprint requests to: Dr. R. G. Labbé, Food Microbiology Laboratory, Department of Food Science, University of Massachusetts, Amherst, Massachusetts 01003 U.S.A. 
Several cell wall hydrolases active on Micrococcus cell walls are reportedly present in $C$. perfringens (28). Enzymes which cause the germination of spores of Bacillus cereus (5), Bacillus megaterium (11) and $C$. perfringens $(1,16)$ have also been reported. The latter enzymes were obtained by extraction of the respective spores. We report here the presence and extraction of another peptidoglycan lytic enzyme from C. perfringens, this one associated with the vegetative cell.

\section{MATERIALS AND METHODS}

Bacterial strains. The organism used was $C$. perfringens type A strains of NCTC 8798. Cells of two asporogenic stage 0 mutants of NCTC 8798, strains 8-16, and 8-62 were also used. All strains were originally obtained from C. Duncan and were maintained in cooked meat medium (Difco).

Media. Cells were grown at $37^{\circ} \mathrm{C}$ in a complex (DS) sporulation medium(7) using raffinose $(0.4 \%)$ as the carbohydrate $(26)$. The medium was inoculated $(1 \%$ inoculum) with cells grown overnight in fluid thioglycollate medium (Difco). In preliminary experiments the effectiveness of starch $(0.4 \%)$ vs. raffinose was compared. For preparation of cell walls, cells were grown in a medium composed of $1.5 \%$ casitone, $0.5 \%$ yeast extract, $0.8 \%$ dextrose, $0.05 \%$ sodium thioglycollate and $1 \%$ sodium phosphate (dibasic).

Preparation of cells. Six $\mathrm{h}$ cells were harvested from DS medium by centrifugation. To remove any contaminating extracellular enzymes and proteins these pellets were washed twice at $5^{\circ} \mathrm{C}$ with $50 \mathrm{~mm}$ Tris- $\mathrm{HCl}$ buffer, $\mathrm{pH} 8.0$ containing $250 \mathrm{~mm} \mathrm{NaCl}$ then twice with the same buffer without $\mathrm{NaCl}$. The washed cells were used for subsequent experiments.

Buffers. Buffer A consisted of $50 \mathrm{~mm}$ sodium citrate, $\mathrm{pH} 6.5$; buffer B contained $50 \mathrm{~mm}$ Tris- $\mathrm{HCl}, \mathrm{pH} 8.0$ at $5^{\circ} \mathrm{C}, 0.15 \mathrm{M} \mathrm{NaCl}$ and protease inhibitors $\left(1.8 \times 10^{-3} \mathrm{~mm}\right.$ phenylmethane sulfonylfluoride and $2.1 \mathrm{~mm}$ ethylenediaminetetraacetic acid). Buffer $\mathrm{C}$ consisted of $50 \mathrm{~mm}$ glycine-hydroxide, $\mathrm{pH} 10.0$, and buffer $\mathrm{D}$ was composed of $50 \mathrm{~mm}$ sodium phosphate, $\mathrm{pH} 6.5$.

Peptidoglycan hydrolase ( $P G H$ ) assay. The assay for peptidoglycan hydrolase was based on the ability of the enzyme to cause the germination of spores of the same strain whose coats had been chemically removed. The procedure, done in duplicate, was similar to that described by Franceschini and Labbé (12). To remove coat protein cleaned spores were suspended in sodium dodecyl sulfate $(0.5 \%)$ plus dithiothreitol $(50 \mathrm{~mm})$ in buffer $\mathrm{C}$ for $2 \mathrm{~h}$ at $37^{\circ} \mathrm{C}$. The treated spores were centrifuged $(10,000 \times g, 15 \mathrm{~min})$ washed three times with distilled water and resuspended in a sufficient volume of buffer $A$ to result in an absorbance $(600 \mathrm{~nm})$ of $0.4-0.5$. The assay mixture consisted of $2 \mathrm{ml}$ of spore suspension and $0.1-0.5 \mathrm{ml}$ of enzyme, the volume of enzyme added depending on the enzyme activity. The decrease in absorbance $(600 \mathrm{~nm})$ of the spore suspension which accompanies loss of spore refractility was measured in a Beckman model 25 spectrophotometer equipped with a kinetic system. One unit of activity was defined as the amount producing a decrease 
in absorbance of $0.001 / \mathrm{min} / \mathrm{ml}$. In most cases results are expressed as $\mathrm{U} / \mathrm{ml}$ of extracted cells. To standardize results, washed cells were resuspended on a weight basis before extraction (see below). Results in tables are given as means of duplicate experiments.

Cell disruption: sonication. The intracellular spore-lytic enzyme was extracted from washed cells by sonication or autolysis. In the case of sonication a $25 \%$ suspension ( $\mathrm{w} / \mathrm{v}$, wet weight) of cells was prepared in buffer $\mathrm{B}$, placed on ice and sonicated intermittantly until few intact cells remained. The disrupted cell suspension was centrifuged at $16,000 \times g$ for $20 \mathrm{~min}$. The supernatant fluid was kept. In one series of experiments the pellet was resuspended in the same initial volume of buffer B and extracted four more times. Extracts obtained by using high salt concentrations were dialyzed against several changes of buffer B before assay.

Cell disruption: autolysis. A $25 \%(\mathrm{w} / \mathrm{v})$ suspension of washed cell pellet was prepared using buffer $\mathrm{B}$. The suspension was incubated in a $37^{\circ} \mathrm{C}$ water bath until autolysis was complete (about $2 \mathrm{~h}$ ). The autolysate was centrifuged at $16,000 \times g$ for $20 \mathrm{~min}$ and the supernatant fluid was saved as crude extract.

Inactivation of spore-lytic enzyme. Cellulose phosphate-purified spore lytic enzyme $(110 \mathrm{U} / \mathrm{ml})$ was heated at $100^{\circ} \mathrm{C}$ for $10 \mathrm{~min}$ or treated with Pronase $(200 \mathrm{~g} / \mathrm{ml}$, Calbiochem) for $30 \mathrm{~min}$ at $37^{\circ} \mathrm{C}$. Activity was assayed as described above.

Preparation of fluorescamine-labelled cortical fragments. Fluorescaminelabelled cortical fragments and time course studies of their hydrolysis with PGH was performed as previously described for initiation preotein (34).

Preparation of cell walls. Late $\log$ phase cells $(5 l)$ were collected by centrifugation at $10,000 \times g$ for $20 \mathrm{~min}$. The pellet was autoclaved for $10 \mathrm{~min}$ to inactivate lytic enzymes and suspended in $200 \mathrm{ml}$ of $50 \mathrm{~mm}$ sodium phosphate buffer, $\mathrm{pH}$ 7.0. The cells were disrupted by sonication with glass beads $(710-1,180 \mu \mathrm{m}$, Sigma). Crude wall fragments were collected by centrifugation at $27,000 \times g$ for $30 \mathrm{~min}$, resuspended in $0.05 \mathrm{~m}$ glycine-hydroxide buffer, $\mathrm{pH} 10$, containing $1 \%$ sodium dodecyl sulfate. The mixture was stirred at $37^{\circ} \mathrm{C}$ for $16 \mathrm{~h}$. The cell walls were collected by centrifugation and resuspended in $100 \mathrm{ml}$ of $50 \mathrm{~mm}$ sodium phosphate buffer, $\mathrm{pH}$ 7.0. Trypsin and ribonuclease (final concentrations each: $0.5 \mathrm{mg} / \mathrm{ml}$ ) were added and the mixture was incubated with stirring at $37^{\circ} \mathrm{C}$ for $4 \mathrm{~h}$. The treated walls were washed consecutively with cold distilled water four times, $2 \mathrm{~m}$ sodium chloride twice and distilled water twice. The walls were then heated for $10 \mathrm{~min}$ in a boiling water bath to inactivate the trypsin and ribonuclease. After two further washings with distilled water the pelleted walls were collected by centrifugation and stored at $-20^{\circ} \mathrm{C}$.

Hydrolysis of cell wall fragments. Thawed cell wall fragments were suspended in $10 \mathrm{~mm}$ sodium phosphate buffer, $\mathrm{pH} 6.5$, sonicated for 1 min to disrupt clumps and adjusted to an absorbance $(600 \mathrm{~nm})$ of 0.45 to 0.50 . For time course studies $1.5 \mathrm{ml}$ of cellulose-phosphate purified PGH (initial activity $2,000 \mathrm{U} / \mathrm{ml}$ ) were added to $15 \mathrm{ml}$ of prewarmed $\left(45^{\circ} \mathrm{C}\right)$ cell wall fragments. Samples $(2 \mathrm{ml})$ were removed periodically and the reaction was stopped by boiling for $7 \mathrm{~min}$. Residual wall 
fragments were removed by centrifugation at $13,000 \times g$ for $5 \mathrm{~min}$ and the supernatant fluid was passed through a $0.2 \mu \mathrm{m}$ filter prior to analysis of free amino groups. As a control PGH was heated at $100^{\circ} \mathrm{C}$ for $10 \mathrm{~min}$ before assay. Hydrolysis of wall fragments at $45^{\circ} \mathrm{C}$ was followed for $2 \mathrm{~h}$ and was monitored as loss in absorbance at $600 \mathrm{~nm}$.

Chemical assays. Protein determination was done by the method of Bradford (3) using bovine serum albumin as a standard. Free amino groups were determined by the method of Ghuysen et al.(13) and reducing sugars by the ferricyanide reduction method of Park and Johnson (31).

$\mathrm{pH}$ optimum determination. Fifty $\mathrm{mm}$ buffers ranging in $\mathrm{pH}$ from 4.5 to 9.0 were prepared as described by Gomori(17). Buffer was mixed with a small volume of coatless spores (suspended in distilled water) to give a final volume of $2.0 \mathrm{ml}$ and a final absorbance $(600 \mathrm{~nm})$ of $0.4-0.5$. The enzyme in Buffer D was mixed with the prewarmed $\left(45^{\circ} \mathrm{C}\right)$ buffer/substrate mixture and assayed for activity.

Effect of cations. Divalent cations $\left(\mathrm{Ca}^{2+}, \mathrm{Mg}^{2+}, \mathrm{Co}^{2+}, \mathrm{Mn}^{2+}\right)$ were added to the assay mixture at final concentrations of 1 and $10 \mathrm{~mm}$. All were in chloride form except $\mathrm{Mn}^{2+}$ which was in sulfate form. Univalent cations $\left(\mathrm{Li}^{+}, \mathrm{Na}^{+}, \mathrm{K}^{+}\right.$, $\mathrm{NH}_{4}^{+}$, all chloride form) were added at final concentrations of 1.0-5.0 mM. The reactions, done in duplicate in a final volume of $2.0 \mathrm{ml}$, were performed by first incubating enzyme $(50 \mu \mathrm{l})$ and ions at $45^{\circ} \mathrm{C}$ for $10 \mathrm{~min}$ before adding substrate.

Polyethyleneimine precipitation. Polyethyleneimine (Sigma) was used to precipitate nucleic acids and acidic proteins from crude extracts. A $10 \%$ stock solution was prepared and adjusted to $\mathrm{pH} 8.0$ using concentrated $\mathrm{HCl}$ as described by Jendrisak and Brugess (23). Polyethyleneimine was added to the crude extract at a final concentration of $0.015 \%(\mathrm{v} / \mathrm{v})$. The mixture was stirred for $10 \mathrm{~min}$ and centrifuged at $16,000 \times g$ for $15 \mathrm{~min}$. The supernatant fluid was saved.

Ammonium sulfate precipitation. The polyethyleneimine-treated crude extract was brought to $70 \%$ saturation with solid ammonium sulfate and stirred gently at $5^{\circ} \mathrm{C}$ overnight. The precipitate was collected by centrifugation $(16,000 \times g, 25 \mathrm{~min})$ and redissolved in $1 / 3$ of the starting volume using buffer $B$. The material was then dialyzed at $4{ }^{\circ} \mathrm{C}$ against several changes of a 20 -fold larger volume of appropriate column-equilibration buffer.

DEAE-Sephacel (anion) chromatography. The redissolved and dialyzed ammonium sulfate precipitate was applied to a column $(1.7 \times 20 \mathrm{~cm})$ of DEAE-Sephacel equilibrated with buffer B. Fractions containing unbounded activity were applied to a cellulose-phosphate column after extensive dialysis against buffer D plus $0.02 \%$ sodium azide.

Cellulose phosphate (cation) chromatography. Cellulose phosphate was hydrated and charged as described by Himmelhoch (22). After packing, the column $2.5 \times 17 \mathrm{~cm}$ ) was washed with 10 bed volumes of $0.5 \mathrm{M}$ sodium phosphate, $\mathrm{pH} 6.5$ then equilibrated with 10 bed volumes of run buffer, i.e. buffer $D$ plus $0.02 \%$ sodium azide. The pooled and dialyzed DEAE-Sephacel eluate was applied to the column at $0.5 \mathrm{ml} / \mathrm{min}$. After application of enzyme, the column was washed with run buffer 
until $280 \mathrm{~nm}$-absorbing material in the eluate was negligible. Enzyme was eluted using a $250 \mathrm{ml}$ linear gradient of $0-0.3 \mathrm{M} \mathrm{NaCl}$ in buffer D. Two $\mathrm{ml}$ fractions were collected and assayed for protein $\left(A_{280}\right)$ and enzyme activity. Fractions with a specific activity of $15 \%$ of maximum or greater were kept.

Hydroxyapatite (adsorption) chromatography. The pooled cellulose phosphate eluate was applied to a column $(1.7 \times 9 \mathrm{~cm})$ of hydroxyapatite previously equilibrated with buffer $D$. The column was then washed with three to four bed volumes of buffer until the eluate was free of $280 \mathrm{~nm}$-absorbing material. The enzyme was eluted with a linear gradient of $0.05-0.3 \mathrm{~m}$ sodium phosphate buffer, $\mathrm{pH}$ 6.5. Fractions of two $\mathrm{ml}$ were collected and assayed for enzyme activity and protein $\left(A_{280}\right)$. Fractions containing enzyme with a specific activity of $50 \%$ of maximum or greater were collected and saved for characterization studies.

The pooled eluates from ion exchange and hydroxyapatite chromatography were concentrated by ultrafiltration using a PM 10 (Amicon) membrane.

Each of three thiol-active agents, mercuric chloride (Fisher Scientific, Fairlawn NJ, U.S.A.), $p$-chloromercuriphenylsulfonic acid (Sigma) and $N$-ethylmaleimide (Sigma) were added to the assay mixture at a final concentration of $10^{-4}$ to $10^{-1} \mathrm{M}$ to examine their effect on enzyme activity. A small volume of coatless spore suspension was mixed with the above reagents in buffer $A$ and prewarmed to $45^{\circ} \mathrm{C}$. Then $50 \mu \mathrm{l}$ of enzyme was added and assayed (in duplicate) for activity. The ability of sodium thioglycollate $(10 \mathrm{~mm})$ to reverse the inhibitory effect was determined by premixing it with enzyme for $2 \mathrm{~min}$ before adding it to the prewarmed spore/inhibitor mixture for assay.

Polyacrylamide gel electrophoresis. Disc gel (7.5\% acrylamide) electrophoresis of basic proteins was performed in duplicate at $\mathrm{pH} 4.3$ as described by Mauer (29) using Pyronin $\mathrm{Y}$ as the tracking dye. In these cases, the electrode connections to the power supply were reversed. One gel was stained with Coomassie blue G-250 and the other sliced $(0.5 \mathrm{~cm})$ to determine enzyme activity. Slices were crushed and extracted with $1 \mathrm{ml}$ of buffer A overnight. Following cellulose phosphate chromatography only one gel band showed PGH enzyme activity. For SDS-PAGE, cellulose phosphate-purified PGH was extracted from 10 cylindrical gels $(10 \%$ enzyme recovery). This material was concentrated using a Centricon 10 concentrator (Amicon) to about $1,000 \mathrm{U} / \mathrm{ml}(0.05 \mathrm{mg}$ protein $/ \mathrm{ml})$ and used for molecular weight determination by SDS-PAGE.

Molecular weight determination by SDS-PAGE. The molecular weight of PGH was determined by sodium dodecyl sulfate-polyacrylamide gel electrophoresis (SDS-PAGE) (5\% acrylamide) (2l) of PGH electrophoretically-purified (by gel electrophoresis) following cellulose-phosphate chromatography. Molecular weight standards ( 8 to $10 \mu \mathrm{g}$; Sigma) were-galactosidase $(116,000)$, phosphorylase b $(97,400)$, bovine albumin $(66,000)$, egg albumin $(45,000)$, and carbonic anhydrase $(29,000)$.

Analytical isoelectric focussing. Analytical isoelectric focussing was performed using $10 \mathrm{~cm}$ tubes of $7 \%$ acrylamide. A pH range of 3-10 was obtained 
using Isolyte (Isolab, Inc.) ampholytes at a final concentration of $3 \%$. The anode and cathode electrodes were composed of $0.003 \mathrm{M} \mathrm{H}_{3} \mathrm{PO}_{4}$ and $0.02 \mathrm{M} \mathrm{NaOH}$ plus $0.02 \mathrm{M} \mathrm{Ca}(\mathrm{OH})_{2}$ respectively. The cellulose-phosphate-purified, ultrafiltrationconcentrated material $(0.68 \mathrm{mg})$ was mixed with the acrylamide before polymerization. Focussing was carried out for $6.5 \mathrm{~h}$ at $200 \mathrm{~V}$ at $4^{\circ} \mathrm{C}$. The gels were sliced in $0.4 \mathrm{~cm}$ sections and eluted in $1 \mathrm{ml}$ deionized, distilled water or in $1 \mathrm{ml}$ $50 \mathrm{~mm}$ citrate buffer, $\mathrm{pH}$ 6.5. Water extracts were used to determine $\mathrm{pH}$. Buffer extracts were used to determine PGH activity.

\section{RESULTS}

\section{Extraction of $P G H$}

Preliminary results indicated that $\mathrm{PGH}$ was produced in large amounts in DS sporulation medium. To determine the necessity for sporulation, cells were grown in DS medium using two different carbohydrates each of which supports different levels of sporulation. Higher PGH levels were obtained using raffinose $(78.4 \mathrm{U} / \mathrm{ml})$ than starch $(1.0 \mathrm{U} / \mathrm{ml})$ in spite of lower sporulation levels $(27 \%$ versus $90 \%)$ in raffinose. The results suggested that the amount of extractable SLE did not depend on the degree of sporulation but rather on the medium composition. To confirm this, PGH activity in vegetative cells and mutant strains was determined. Fluid thioglycollate is a glucose-rich medium in which sporulation does not occur. PGH activity was extractable from both exponential- and stationary-phase cells grown in this medium. Similarly enzyme activity was present in asporogenous mutants of strain NCTC 8798 whether cell disruption was achieved by sonication or autolysis. The use of a French press was less effective than sonication (data not shown).

The above extractions were performed at a low $(0.15 \mathrm{M}) \mathrm{NaCl}$ concentration. When cells were extracted using high salt concentrations, the highest SLE activity was obtained using $3 \mathrm{M} \mathrm{NaCl}$ or $6 \mathrm{M} \mathrm{LiCl}$, although a concentration of $0.15 \mathrm{M} \mathrm{NaCl}$ was quite effective, yielding $75 \%$ of the maximum obtained with $6 \mathrm{M} \mathrm{LiCl}$ (Table 1).

The first extraction of cells with low salt buffer did not remove all SLE activity (Table 2 ); $15-18 \%$ of the total activity could be obtained by each of three additional treatments. The likely source of the SLE in these cases was cells unaffected by the

Table 1. Effect of salt concentration on extraction of PGH from C. perfringens cells.

\begin{tabular}{cc} 
Salt & $\begin{array}{c}\text { Percent of maximum } \\
\text { activity }\end{array}$ \\
\hline $6 \mathrm{M} \mathrm{LiCl}$ & 100 \\
$3 \mathrm{M} \mathrm{LiCl}$ & 83 \\
$3 \mathrm{M} \mathrm{NaCl}$ & 99 \\
$0.15 \mathrm{M} \mathrm{NaCl}$ & 75
\end{tabular}

Salts were dissolved in $50 \mathrm{~mm}$ Tris- $\mathrm{HCl}$ buffer, $\mathrm{pH} 8.0$ with protease inhibitors; cells were grown in DS-raffinose medium for $6 \mathrm{~h}$, washed, and extracted by sonication. 
Table 2. Successive extraction of PGH from $C$. perfringens cells.

\begin{tabular}{ccc}
\hline Order of extraction & $\begin{array}{c}\text { PGH activity recovered } \\
\text { (total units) }\end{array}$ & $\begin{array}{c}\text { Percent of total } \\
\text { extracted }\end{array}$ \\
\hline 1st & 105,000 & 45 \\
2nd & 41,800 & 18 \\
3rd & 36,600 & 17 \\
4th & 33,600 & 15 \\
5th & 14,000 & 6 \\
\hline
\end{tabular}

Cells were grown in $20 \mathrm{l}$ of DS-raffinose for $6 \mathrm{~h}$ then washed and extracted five times by sonication in buffer $\mathrm{B}$.

Table 3. Summary of purification of $C$. perfringens peptidoglycan hydrolase.

\begin{tabular}{lccccc}
\hline \multicolumn{1}{c}{ Step } & $\begin{array}{c}\text { Total protein } \\
(\mathrm{mg})\end{array}$ & $\begin{array}{c}\text { Total activity } \\
\left(\text { units } \times 10^{-3}\right)\end{array}$ & $\begin{array}{c}\text { Sp. activity } \\
(\text { units } / \mathrm{mg})\end{array}$ & $\begin{array}{c}\text {-Fold } \\
\text { purification }\end{array}$ & \% yield \\
\hline $\begin{array}{l}\text { Crude extract } \\
\text { Polyethyleneimine }\end{array}$ & 6,090 & 231 & 38 & 1 & 100 \\
$\quad 3,780$ & 176.4 & 46 & 1.2 & 75.2 \\
$\quad$ supernatant & 1,129 & 233.8 & 207 & 5.5 & 101 \\
Ammonium sulfate & 110 & 290.2 & 2,586 & 68.2 & 125 \\
DEAE-Sephacel & 8.0 & 100 & 12,500 & 330 & 43.3 \\
Cellulose phosphate & 1.7 & 87.0 & 51,176 & 1,347 & 37.6 \\
\hline
\end{tabular}

preceding sonication treatments. It is likely that the efficiency of the latter is affected by the increased viscosity associated with the release of proteins and nucleic acids requiring their periodic removal by centrifugation.

\section{Appearance of $P G H$ during growth}

The appearance of PGH during growth of strain NCTC 8798 in DS medium was followed in cells grown in DS medium. Enzyme activity from cells, resuspended on a weight basis before extraction, was highest at $6 \mathrm{~h}$ (Fig. 1). This reflected the achievement of a stationary phase at that time.

\section{Purification and properties of $P G H$}

The procedure used to purify the PGH is shown in Table 3. Polyethyleneimine was found to be a simple method for the removal of nucleic acids without adding RNAse or DNAse. PGH did not bind to DEAE-Sephacel but this medium did remove significant amounts of contaminating protein. An inhibitor was also apparently removed since total activity increased after this step. The elution profile of PGH following cellulose phosphate and hydroxyapatite chromatography is shown in Fig. 2. The final yield of the PGH was $37.6 \%$ with a 1,347 -fold purification. The hydroxyapaptite-purified material showed three bands one of which was associated with PGH activity (not shown). Attempts at further purification was unsuccessful 


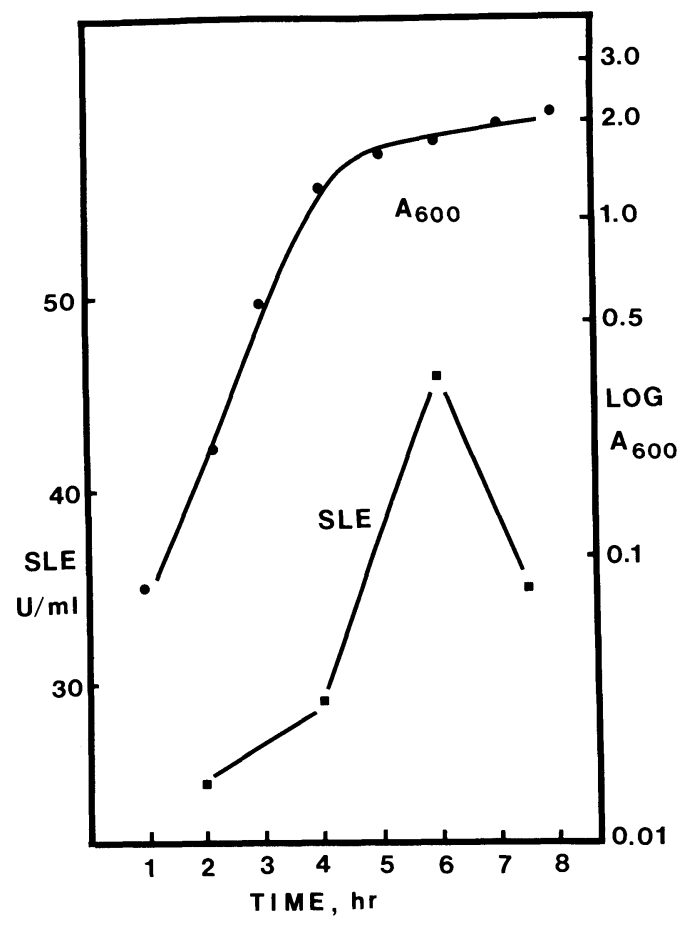

Fig. 1

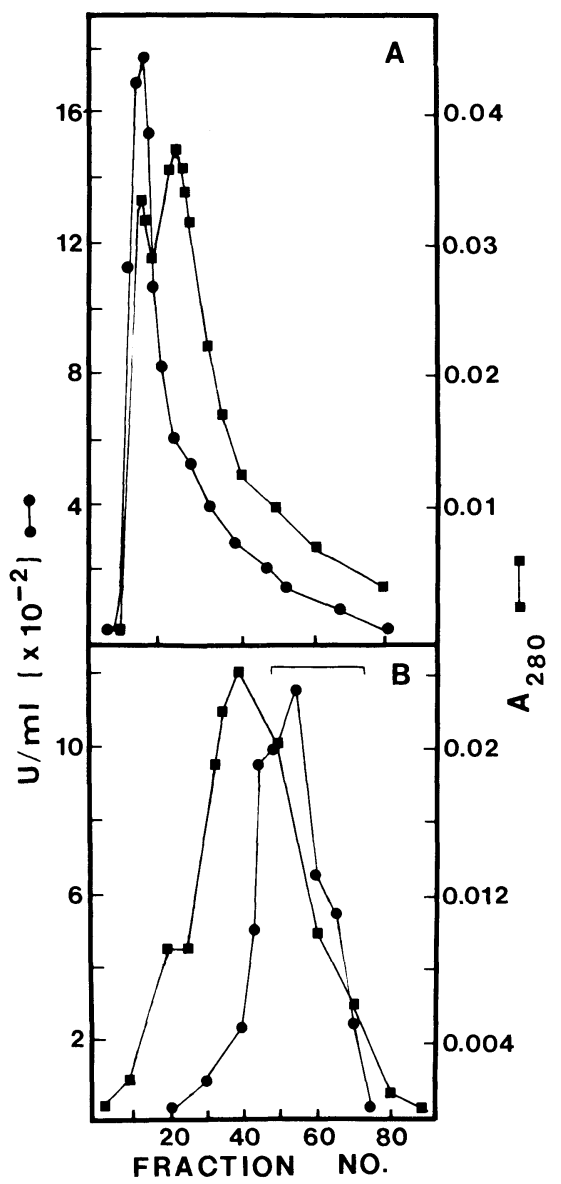

Fig. 2

Fig. 1. Growth and spore-lytic enzyme (peptidoglycan hydrolase) activity in $C$. perfringens NCTC 8798 grown in DS medium with raffinose as the carbohydrate source. Duplicate one hundred $\mathrm{ml}$ samples were taken at various times from a $1-l$ culture, washed and extracted by sonication as described in METHODS. Maximum sporulation occurred at $6 \mathrm{~h}$. Results are from duplicate assays.

Fig. 2. Chromatography of PGH on cellulose-phosphate and hydroxyapatite. (A) Unbound protein from a DEAE-Sephacel was applied to a cellulose phosphate column. (B) Fractions 20-40 were pooled and applied to a hydroxyapatite column. Pooled fractions indicated by a bar were analyzed by polyacrylamide gel electrophoresis.

due to the extreme lability of the hydroxyapatite-purified PGH.

The molecular weight of PGH was 125,000 as determined by SDS-PAGE. The isoelectric point was 7.6. Alkaline $\mathrm{p} I \mathrm{~s}$ have been reported for other bacterial lytic enzyme (2). A distinct pH optimum of 6.0 was obtained (not shown).

Neither divalent ions (1 to $10 \mathrm{~mm}$ ) nor monovalent ions (10 to $50 \mathrm{~mm}$ ) stimulated 


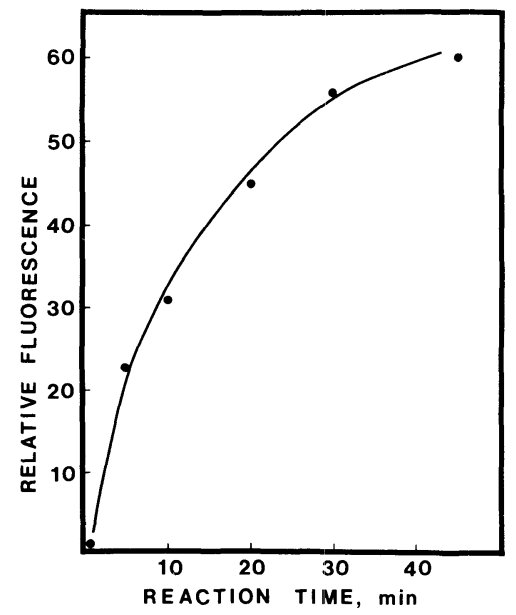

Fig. 3

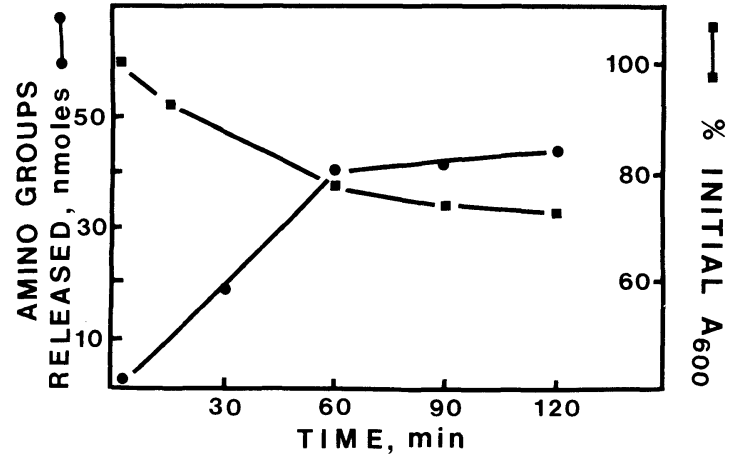

Fig. 4

Fig. 3. Kinetics of release by $\mathrm{PGH}$ of soluble fluorescent products during hydrolysis of fluorescamine-labelled spore cortical fragments of $C$. perfringens.

Fig. 4. Release of amino groups by PGH (•) during hydrolysis ( $\bullet$ ) of $C$. perfringens vegetative cell wall fragments.

PGH activity. On the contrary all except cobalt, which had no effect, inhibited PGH. This could be due to ionic strength effects since the inhibitory effects were concentration-dependent (not shown).

The thiol-active agents, mercuric chloride, $p$-chloromercuriphenylsulfonic acid, and $N$-ethylmaleimide completely inhibited activity at concentrations of $0.1,10$, and $100 \mathrm{~mm}$ respectively. Most of the inhibition was reversible by preincubation of the enzyme with sodium thioglycollate $(10 \mathrm{~mm}$, not shown). This suggests a role for sulfhydryl groups in maintaining enzyme activity. No enzyme activity remained if the preparation was treated for $10 \mathrm{~min}$ at $100^{\circ} \mathrm{C}$ or treated with pronase.

The enzyme also hydrolyzed fluorescamine-labelled cortical fragments. This was indicated by the release of soluble, fluorescent end products. Most of these labelled end products had appeared within $30 \mathrm{~min}$ (Fig. 3). None appeared if the PGH was boiled for 10 min before the assay. The results indicate that PGH causes spore germination because of its direct action on the spore cortex. This and the following characterization studies were performed using cellulose phosphate-purified material. Gel electrophoresis of this preparation revealed five bands, only one of which had PGH activity.

Treatment of cell wall fragments with PGH resulted in their hydrolysis and a concomitant release of free amino groups (Fig. 4). Within $1 \mathrm{~h}$ absorbance was reduced to about $75 \%$ of the initial value. No reducing sugars were detected. No enzyme activity was observed if PGH was boiled $10 \mathrm{~min}$ before assay. The results indicated that $\mathrm{PGH}$ is a peptidase or an amidase but not an endo- $\beta-N$ - 
acetylglucosaminidase or endo- $\beta$ - $N$-acetylmuramidase.

\section{DISCUSSION}

In this study we have extracted and partially purified a lytic enzyme active on both spore cortex and vegetative cells of $C$. perfringens. The enzyme causes the germination of sensitized spores. Also, it has a molecular weight of 125,000 , causes the release of soluble fluorescent products from fluorescamine-labelled cortical fragments, and hydrolyses cell wall fragments. The enzyme was inhibited by sulfhydryl agents as well as by various monovalent and divalent cations. In these respects it is similar to the extracellular spore-lytic enzyme of $C$. perfringens, Initiation Protein (27). The differences between IP and the PGH isolated here were, respectively, 1) a molecular weight of 100,000 vs. $125,000,2$ ) a broad $\mathrm{pH}$ optimum of between 6 and 7 vs. a distinct $\mathrm{pH}$ optimum of $6.0,3$ ) isoelectric points of 7.9 vs. 7.6, and 4) an ability to hydrolyze cortical fragments of $C$. perfringens (as determined by a loss in absorbance) vs. lack of such activity under the same assay conditions. It is likely that these two proteins are distinct. On the other hand in one Bacillus species it was shown that a cloned cell wall hydrolase gene could express several forms due to proteolytic processing (33). C. perfringens has both intracellular and extracellular proteases (Park and Labbé, unpublished (18)). This may indicate that IP and PGH represent the same gene product but with post-translational modifications. Amino acid sequence analysis could clarify this point. To date limited quantities of each enzyme have precluded such an analysis.

Our previous results dealing with germination enzymes from intact $C$. perfringens spores $(15,16)$ led to our present attempts at identifying similar lytic activity within sporulating cells of this organism. Such enzymes have been identified in Bacillus thuringiensis to be an $N$-acetylmuramyl-L-alanine amidase and an endopeptidase (24). Similar enzymes have also been reported in sporulating cells of Bacillus sphaericus (20) and Bacillus subtilis (19). However, in the work described here we found no association of extractable enzyme activity and sporulation. Both vegetative cells and asporogenic mutants contained PGH activity. This is the first report of a spore-lytic enzyme present within vegetative cells of spore-forming bacteria.

Although there was no association of PGH with sporulation of this organism we chose a sporulation medium for further work because of the higher enzyme yields from cells grown in it. The highest activity was obtained from early stationary-phase cells and decreased in later phases. At about $8 \mathrm{~h}$ of growth in DS medium, some autolysis begins. This may account for the fall in total activity at this time.

A high salt concentration was not necessary to extract the bulk of this enzyme, suggesting it is not tightly bound to the cell wall as has been reported for autolysins from $C$. perfringens and Bacillus subtilis vegetative cells for which $3 \mathrm{M}$ or $5 \mathrm{M} \mathrm{LiCl}$ was used for extraction $(4,8,36)$. PGH seems to be a soluble cytoplasmic enzyme. 
The function of the PGH described here remains unclear. It is tempting to assign it a role in germination or sporulation. However it differs in size and other characteristics from the native germination enzyme extracted from spores of this organism(16). In addition it was produced during growth, in the absence of sporulation. It may be a lytic enzyme involved in cell division or cell wall turnover and happens to affect spore cortex the basic structure of which appears to be similar to vegetative wall peptidoglycan (35). Lytic enzymes from vegetative Bacillus sp. have been implicated in the turnover of cell wall peptidoglycan during growth $(14,32)$ and in the separation of daughter cells at the time of cell division $(9,10)$. Since PGH is not a glycosidase it is distinct from previously-reported autolysins from $C$. perfringens (36).

This work was supported by the U.S. Army Research Office.

\section{REFERENCES}

1) Ando, Y. J., Spore lytic enzyme released from Clostridium perfringens. J. Bacteriol., 140, 59-64 (1979).

2) Bierbaum, G. and Sahl, H.-G., Autolytic systems of Staphylococcus simulans 22: Influence of cationic peptides on activity of $N$-acetylmuramoyl-L-alanine amidase. J. Bacteriol., 169, 5452-5458 (1987).

3) Bradford, M., A rapid and sensitive method for the quantitation of microgram quantities of protein utilizing the principle of protein-dye binding. Anal. Biochem., 72, 248-254 (1976).

4) Brown, W., Binding and release from cell walls: A unique approach to the purification of autolysins. Biochem. Biophys. Res. Commun., 47, 993-996 (1972).

5) Brown, W., Cuhel, R., and Greer, C., Isolation and properties of a surface bound cortex-lytic enzyme from spores of Bacillus cereus T. In Spore Research 1976, ed. by Barker et al., Academic Press, London (1977), p. 335-349.

6) Cassier, N. and Sebald, M., Germination lysozyme-dependante des spores de Clostridium perfringens ATCC 3624 apres traitment thermique. Annal. Inst. Past., 117, 312-324 (1969).

7) Duncan, C. L. and Strong, D. H., Improved medium for sporulation of Clostridium perfringens. Appl. Microbiol., 16, 82-89 (1968).

8) Fan, D. J., Cell wall binding properties of the Bacillus subtilis autolysin(s). J. Bacteriol., 103, 488-493 (1970).

9) Fein, J. and Rogers, H., Autolytic enzyme-deficient mutants of Bacillus subtilis. J. Bacteriol., 127, 1427-1442 (1976).

10) Forsberg, C. and Rogers, H., Characterization of Bacillus licheniformis 6346 mutants which have altered lytic enzyme activity. J. Bacteriol., 118,358-368 (1974).

11) Foster, S. and Jonhstone, K., Purification and properties of a germination-specific cortex-lytic enzyme from spore of Bacillus megaterium KM. Biochem. J., 242, 573-579 (1987).

12) Franceschini, T. and Labbé, R., Sensitivity of chemically-treated spores of Clostridium perfringens type A to an initiation protein. Microbios, 25, 85-91 (1979).

13) Ghuysen, J., Tipper, D., and Strominger, J., Enzymes that degrade bacterial walls. Methods Enzymol., 8, 685-699 (1966).

14) Glaser, L. and Lindsay, B., Relation between cell wall turnover and cell growth in Bacillus subtilis. J. Bacteriol., 130, 610-619 (1977).

15) Gombas, D. and Labbe, R., Extraction of spore-lytic enzyme from Clostridium perfringens spores. J. Gen. Microbiol., 126, 37-44 (1981). 
16) Gombas, D. and Labbé, R., Purification and properties of spore-lytic enzymes from Clostridium perfringens type A. J. Gen. Microbiol., 131, 1487-1496 (1985).

17) Gomori, G., Preparation of buffers for use in enzyme studies. Methods. Enzymol., 1, 138-146(1955).

18) Granum, P., Whitaker, J., and Skjelkvale, R., Trypsin activation of enterotoxin from Clostridium perfringens type A. Biochim. Biophys. Acta, 668, 325-333 (1981).

19) Guinand, M., Michel, G., and Balassa, G., Lytic enzymes in sporulating Bacillus sphaericus. Biochem. Biophys. Res. Commun., 68, 1287-1293 (1976).

20) Guinand, M., Michel, G., and Tipper, D., Appearance of $\gamma$-glutamyl-L-mesoaminopimelate peptidoglycan hydrolase during sporulation of Bacillus sphaericus. J. Bacteriol., 120, 173-184 (1974).

21) Hames, B. and Rickwood, D., An introduction to polyacrylamide gel electrophoresis. In Gel Electrophoresis of Proteins, ed. by Hames, B. and Rickwood, D., IRL Press, Washington, D.C. (1984), p. 1-91.

22) Himmelhoch, S., Chromatography of proteins on ion-exchange absorbents. Methods Enzymol., 22, 273-286 (1971).

23) Jendrisak, J. and Burgess, R., A new method for the large scale purification of wheat germ DNA-dependent RNA polymerase II. Biochemistry, 4, 4639-4645 (1975).

24) Kingan, S. and Ensign, J., Isolation and characterization of three autolytic enzymes associated with sporulation of Bacillus thuringiensis. J. Bacteriol., 96, 629-638 (1968).

25) Labbe, R. G. and Tang, S., Conditions for production of initiation protein for germination of Clostridium perfringens spores. Can. J. Microbiol., 29, 829-832 (1983).

26) Labbe, R. and Rey, D., Raffinose increases sporulation and enterotoxin production by Clostridium perfringens type A. Appl. Environ. Microbiol., 37, 1196-1200 (1979).

27) Labbe, R. G., Tang, S., and Francischini, T., Partial purification and characterization of an initiation protein for germination from Clostridium perfringens spores. Biochim. Biophys. Acta, 678, 329-333 (1981).

28) Leclerc, D. and Asselin, A., Detection of bacterial cell wall hydrolases after denaturing polyacrylamide gel electrophoresis. Can. J. Microbiol., 35, 749-753 (1989).

29) Mauer, H., Disc Electrophoresis, 2nd ed., Walter de Gruyter, New York (1971), p. 4446.

30) McDonel, J., Clostridium perfringens toxins (Types A, B, C, D, E), Pharmacol. Ther., 10, 617-655 (1979).

31) Park, J. and Johnson, M., A submicro determination of glucose. J. Biol. Chem., 181, 149-151 (1949).

32) Pooley, H., Turnover and spreading of old wall during surface growth of Bacillus subtilis. $J$. Bacteriol., 125, 1127-1138 (1976).

33) Potivin, C., Leclerc, D., Tremblay, G., Asselin, A., and Bellemare, G., Cloning, sequencing and expression of a Bacillus bacteriolytic enzyme in Escherichia coli. Mol. Gen. Gen., 214, 241-248 (1988).

34) Tang, S. and Labbé, R., Fluorescamine-labelled cortical fragments as a substrate for lysozyme and initiation protein (spore lytic enzyme). J. Microbiol. Meth., 6, 185-190 (1987).

35) Tang, S. and Labbé, R., Mode of action of Clostridium perfringens Initiation Protein (spore-lytic enzyme). Ann. Past. Inst. (Microbiol.), 138, 597-608 (1987).

36) Williamson, R. and Ward, J., Characterization of the autolytic enzymes of Clostridium perfringens. J. Gen. Microbiol., 114, 349-354 (1979). 